\title{
Saccharomyces cerevisiae'nın Gelişme Ortamına İlave Edilen Ăğır Metallerin (Mn, Mg, Cd, Fe) Bazı Biyokimyasal Parametrelere Etkileri
}

\author{
Oğuz Ayhan KİREÇCi \\ Bitlis Eren Üniversitesi Hizan MYO, Bitkisel ve Hayvansal Üretim Bölümü, BİTLİS \\ $\triangle$ : kireccioguzayhan@gmail.com
}

Geliş (Received): 20.10.2016

Kabul (Accepted): 20.12.2016

\begin{abstract}
ÖZET: Ağır metaller; düşük konsantrasyonlarda bile toksik veya zehirleyici olabilen yüksek yoğunluklu metallerdir. Ağır metaller belirli bir zaman aralığında canlı organizmada diğer metallere oranla daha fazla birikir. Sonuç olarak giderek artan olumsuz etkilere sebep olur. Araştırmada kullanılan Saccharomyces cerevisiae metal biyo absorbsiyonu çalışmalarında sıklıkla kullanılmaktadır. S. cerevisiae ile yapılan bu çalışma ile ilk kez $\mathrm{Mn}, \mathrm{Mg}, \mathrm{Cd}$ ve $\mathrm{Fe}$ metal iyonlarının lipit peroksidasyonu (MDA), glutatyon (GSH), yăg asidi ve vitamin içerikleri gibi bazı biyokimyasal parametreler üzerine etkileri araștııılmıştır. Deneyde kullanılan S. cerevisiae FMC16'nın gelişimi ve çoğalması için YEDP besiyeri ortamı hazırlandı. Uygulama grupları için; $\mathrm{Mn}, \mathrm{Mg}, \mathrm{Cd}$ ve Fe ağır metallerinin her birinden $2 \mathrm{mg}$ 200$1 \mathrm{~mL}$ olacak şekilde kültür ortamına ilave edildi. Elde edilen süpernatan ile, GSH (Elman reaktifi ile), total protein (Lowry yöntemine göre) ve MDA (Ohkawa ve ark.'nın spektrofometrik yöntemine göre), yağ asitleri (Christie'ye göre) ve vitamin (Katsanidis ve Addis'e göre) analizleri yapıldı. Sonuç olarak, ağır metal uygulamasının MDA ve GSH içeriklerini önemli seviyede artırdığı ve bu artışların istatistiksel açıdan da önemli olduğu $(\mathrm{p}<0.0001)$ belirlenmiştir. Buna karşılık; ağır metallerin yağ asidi ve vitamin içeriği üzerine etkilerinin oldukça değişken olduğu anlașıllmıștır. S. cerevisiae'dan elde edilen bu sonuçlar ekosistemi oluşturan bütün ökaryotik organizmalara uyarlandığında, özellikle çevrede ve besinlerde birikimi oldukça yüksek olan bu ağır metallerin tüketimine dikkat edilmesi gerektiği sonucuna ulaşılmaktadır.
\end{abstract}

Anahtar Kelimeler: Ağır metal, S. cerevisiae, malondialdehit (MDA), glutatyon (GSH), yağ asidi

\section{Effect of Heavy Metals (Manganese, Magnesium, Cadmium, and Iron) added Saccharomyces cerevisiae Culture Medium on Some Biochemical Parameters}

\begin{abstract}
Heavy metals are high density metals that can be toxic even at low concentrations. Heavy metals accumulate in living organisms at a greater rate than other metals in a certain time interval. As a consequence, they result gradually increasing negative effects. Saccharomyces cerevisiae used in this study is frequently preferred in metal bioabsorption. The effects of $\mathrm{Mn}, \mathrm{Mg}, \mathrm{Cd}$ and $\mathrm{Fe}$ metal ions on some biochemical parameters such as lipid peroxidation (MDA), glutathione (GSH), fatty acid and vitamin contents were investigated for the first time in this study with S. cerevisiae. For the development and proliferation of S. cerevisiae FMC16 in the study, YEDP ( $1 \mathrm{~g}$ yeast extract for $100 \mathrm{ml}, 2 \mathrm{~g}$ bactopeptone, $2 \mathrm{~g}$ glucose) medium was used. For application groups; $2 \mathrm{mg} 200-1 \mathrm{~mL}$ of each of heavy metals including $\mathrm{Mn}, \mathrm{Mg}, \mathrm{Cd}$ and Fe were added to the culture medium. GSH (with Elman Reactivity), total protein (according to Lowry) and MDA (according to the spectrophotometric method of Ohkawa et al.), fatty acid (according to Christie) and vitamins (according to Katsanidis and Addis) analyzes were performed with the obtained supernatant. Results indicated that heavy metal application increased MDA and GSH contents significantly (p $<0.0001)$. Whereas, it is concluded that heavy metals have various effects on fatty acids and vitamin content and are accumulating a high degree in environment and organisms. Thus, all living organisms should avoid consuming any of these heavy metals.
\end{abstract}

Keywords: Heavy metal, S. cerevisiae, fatty acid, glutathione, vitamin

\section{GíRiş}

Ağır metaller parçalanabilir olmadıkları için yaygın çevre kirleticileridir. $\mathrm{Bu}$ metaller çeșitli sektörlerde kullanılmaktadır ve dolayısıyla atıklarını çevreye vermektedir (Zouboulis ve ark., 2004). Mikrobiyal topluluklar; değişik formlardaki metallerin çevreye girişini sağlayabilir (Doelman ve ark., 1994). Bazı ağır metaller temel iz elementler olmalarına rağmen, yüksek konsantrasyonlarda bitkiler, hayvanlar ve mikroplar için toksiktir. Ağır metallerin genellikle mikroorganizmalar tarafindan inhibe edici bir etki ile önemli fonksiyonel grupları bloke edilir veya önemli metal iyonlarının yeri değiştirilir (Doelman ve ark., 1994).

Ağır metaller içerisinde kurşun, çinko, bakır, kobalt, kadmiyum, krom, mangan, arsenik, magnezyum, demir ve gümüş gibi metal iyonları, kalıcı etkilerinden dolayı canlı sistemleri ve çevre sağlığı yönünden önem taşımakta olup, belirli bir sınırı aşınca da son derece toksik etki göstermektedir. Bazı sistemlerde ağır metallerin etki mekanizması konsantrasyona bağlı olarak değişir. Konsantrasyon sınırını aştıkları zaman toksik etki gösteren ağır metaller canlı bünyelerde sadece konsantrasyonlarına bağlı olarak etki göstermezler. Sebep oldukları etki, canlı türüne ve metal iyonunun yapısına bağlı olarak da değişir. Kadmiyum uygulamasının MDA miktarının dokularda artmasına sebep olduğu bildirilmiștir (Asagba ve ark., 2000). Farres ve ark., (2016) yaptıkları çalışmalarında ağır metal 
grubunda olan $\mathrm{Cu}$ (bakır)'ın $\mathrm{S}$. cerevisiae'de ki toksik etkilerini araştırmışlar ve araştırma sonucunda mayada ağır metalin oksidatif stres oluşumuna neden olarak DNA hasar1 oluşturduğunu gözlemlemişlerdir. Bir diğer ağır metal olan $\mathrm{Pb}$ (kurşun)'nun S. cerevisiae mayasında etkilerinin araştırıldığı bir çalışmada; Pb'nin oksidatif stresi arttırıcı bir etkinin olduğu saptanmış ve bu artışın mayanın mitokodrisinde hasara yol açtığ 1 ortaya konulmuştur (Sousa ve Soares 2014). Mukherjee ve ark. (2010)'nın arsenik konsatrasyonunun Aspergillus niger üzerindeki etkilerini araştırdıkları çalışmaları sonucunda, konsatrasyon artışına bağlı olarak MDA seviyesinde artış olduğunu belirtmişlerdir. Ancak günümüze kadar yapılan çalışmalar kapsamında ağır metallerin S. cerevisiae mayasında MDA düzeyi, yağ asidi ve vitamin profilleri üzerine olan etkisini ortaya koymaya yönelik literatür bilgisi bulunmamaktadır.

Yüksek yapılı organizmalarda ve mayalarda mikroelementlerin etkileri son yıllarda araştırmalara sıkça konu olmaktadır. Özellikle çinko, bakır, demir, krom, selenyum ve mangan gibi elementlerin insan ve hayvanlarda hastalıkları önleme etkilerinin yanı sıra maya metabolizması üzerindeki etkileri de bilimsel çalışmalara konu olmaktadır (Guan-Zetic ve ark., 2001).

Mayalar çeşitli özellikleri sayesinde toksik maddelere karşı direnç gösterebilirken bu direnç etkisini; metal alımı ya da geçişinin azaltılması veya hücrenin metalleri tutması şeklinde farklı iki mekanizma ile gösterebilir (Guan-Zetic ve ark., 2001). Bakır ve çinko gibi ağır metaller hücre metabolizmasında yapısal ve fonksiyonel olarak iş görürken, kadmiyum, civa ve kurşun gibi esensiyal olmayan metaller hücresel fonksiyonlar için zararlı olabilmektedir (Ortiz ve ark., 1992).

Ağır metal ile kirlenmiş bir ortamda hayatta kalabilmek için mikroorganizmalar çeşitli toksik metal iyonlarına karşı dayanıklılık geliştirmiştir (Nies ve Silver, 1995; Nies, 1999). Bu mekanizmalar; metallerin geçirgenliğinin engellenmesi, hücreden metalin aktif şekilde uzaklaştırılması, metallerin bağlanması, hüçre dışına atma ve çeşitli şekillerde metallerin daha düşük toksik forma dönüştürülmesi şeklindedir (Bruins ve ark., 2000; Nies ve Silver, 1995; Silver, 1996). Farklı metallere karşı genel bir direnç mekanizması yoktur ve dayanıklılık bir türden diğerine farklılık gösterir.

Ağır metal iyonları birçok fizyolojik aşamada önemli rol oynamalarına rağmen fazla miktarda ortamda bulunduklarında metabolizmada çok çeșitli ve tehlikeli hasarlara neden olurlar (Avery, 2001; Schützendübel ve Polle, 2002; Gaetke ve Chow, 2003). Ağır metallerden olan kadmiyum (Cd) yer kabuğunda bulunan doğal bir elementtir. Genellikle de diğer elementlerle bileşik oluşturur. Cd yüksek toksisiteye sahiptir. Kalıcı olması nedeniyle besinlerde ve ekosistemde en tehlikeli iz elementlerden birisidir (Carrera ve ark., 1998). Mangan (Mn) önemli metallerden birisidir. Metal sanayinde özellikle çeliğin dayanımını artırmak için kullanılır. Mangan vücutta bazı enzimlerin yapısında kofaktör olarak kullanılmaktadır. Mangan birikimi insanda Parkinson benzeri hastalıklara ve psikotik belirtilere yol açmaktadır (Murray ve ark., 1991). Bunun yanında Mn bitkiler için gerekli olan bir mikro elementtir. Fotosentez, terleme ve biyosentez gibi işlemlerin birçoğunda insan vücudunda olduğu gibi bitki hücrelerinde de rol alır. Yüksek konsantrasyonlarda toksik etkiye sahiptir (Todorović ve ark., 2009). Magnezyum (Mg) yer kabuğunda en bol bulunan 8. doğal elementtir. Mg canlı dokuda enerji oluşumu, taşınması, proteinler, DNA ve RNA gibi önemli moleküllerin oluşturulması için gerekli bir elementtir. Bitkilerde ise klorofil molekülünün merkezinde bulunarak hayati işlev yapar. Dolayısıyla hem bitkiler hem de hayvanlar için önemli bir elementtir. Demir $(\mathrm{Fe})$ oldukça zararlı olabilen ve ciddi toksik etkiler meydana getirebilen bir elementtir. Saf demir olarak doğada bulunması zordur. İnsanlar ve diğer canlılar için hayati öneme sahip olan demir, yüksek dozlarda organizmada ciddi zararlara yol açabilir (Mahesh ve ark., 2008). Demir bitkiler için gerekli olan mikro elementlerden olmasına rağmen yüksek dozlarda toksik etkilere sahiptir (Williams ve ark., 2000). Aynı zamanda insanlarda diyabet, damar rahatsılıkları ve ilgili kardiyovasküler anormallikler, hormonal bozukluklar ve bağışıklık sistemi üzerine zararlı etkileri de bulunmaktadır. Oksidatif stress oluşturarak beyin dokusuna zarar verebilir (Gurzau ve ark., 2003).

Mayalar; günümüzde biyoteknolojik çalışmalara sıkça konu olan organizmalar içerisindedir. Araştırmada kullanılan S. cerevisiae'nın metal biyosorbsiyonunda etkili olarak kullanıldığı bilinmektedir. Ancak günümüze kadar yapılan araştırmalar ile ağır metallerin S. cerevisiae üzerindeki biyokimyasal etkileri tam olarak ortaya konulamamıştır. Bu çalışma ile S. cerevisiae'nın gelişme ortamına ilave edilen $\mathrm{Mn}, \mathrm{Mg}, \mathrm{Cd}$ ve $\mathrm{Fe}$ gibi ağır metallerin biyokimyasal parametreler üzerine etkilerinin araştırılması amaçlanmıştır.

\section{MATERYAL ve METOT}

Saccharomyces cerevisiae'nın Gelişme ve Uygulama Ortamının Hazırlanması

Deneyde kullanılan S. cerevisiae FMC16'nın gelişimi ve çoğalması için YEDP $(100 \mathrm{~mL}$ için $1 \mathrm{~g}$ yeast exrakt, 2 g baktopepton, 2 g glukoz) besiyeri ortamı hazırlandı. Her grup için tekrar sayısı (n) =6 olarak yapıldı. Besiyeri ortamı hazırlandıktan sonra aşağıdaki gruplara ayrıldı;

Kontrol grubu: Bu gruptaki $S$. cerevisiae hücreleri için, $200 \mathrm{~mL}$ saf su içinde $2 \mathrm{~g}$ maya ekstraktı, $4 \mathrm{~g}$ baktopepton ve $4 \mathrm{~g}$ glukoz içeren besiyeri ortamı hazırland1.

Ağır Metal Uygulama Grupları: Bu gruptaki $S$. cerevisiae hücreleri için, gelişme ortamını içeren besiyeri hazırlandıktan sonra $\mathrm{Mn}, \mathrm{Mg}, \mathrm{Cd}$ ve $\mathrm{Fe}$ ağır metallerinin her birinden $2 \mathrm{mg} 200^{-1} \mathrm{~mL}$ olacak şekilde kültür ortamına ilave edildi. Aşılama işleminden sonra kültürler $30{ }^{\circ} \mathrm{C}$ 'de 72 saat inkübasyona birakıld1. Bu sürenin sonunda kültürler laboratuvar şartlarında $517 \mathrm{~nm}$ 'de hücre yoğunlukları ölçüldükten sonra, $6000 \mathrm{rpm}$ 'de 5 dakika süreyle $+4{ }^{\circ} \mathrm{C}$ 'de santrifüj edilerek hücreler toplandı. Hücreler pellet olarak toplandıktan sonra yaş 
ağırlıkları belirlenip diğer biyokimyasal işlemlerin yapılmasına geçildi.

Hücre pelletleri, $20 \mathrm{mM}$ Tris HCl-baz $(\mathrm{pH}=7.4)$ ve 20 mM EDTA karışımı ile homojenize edilip santrifüj edildikten sonra süpernatant kısmı ile GSH, total protein ve MDA ölçümleri yapıldı ve geriye kalan pellet $10 \mathrm{~mL}$ $3 / 2$, (v/v) oranında n-hekzan/izopropanol karışımı ile homojenize edilerek yağ asidi düzeyi, sterollerin (ergosterol, stigmasteol, $\beta$-sitosterol) analizi yapıldı.

Sonuçlar SPSS istatistik programı kullanılarak analiz edilip farklılıklar istatistik açıdan değerlendirildi.

Maya Hücresinde MDA Miktarının Ölçülmesi

MDA (TBARS) düzeyinin ölçümü, Ohkawa ve ark., (1979) 'nin metoduna göre bazı modifikasyonlar yapılarak spektrofotometre ile ölçüldü.

Maya Hücresinde Glutatyon Miktarının Ölçülmesi

Süpernatant k1sım üzerine $0.3 \quad \mathrm{M} \quad \mathrm{Na}_{2} \mathrm{HPO}_{4}$ çözeltisinden $2 \mathrm{~mL}$ ilave edildi ve $0.5 \mathrm{~mL} \% 0.03$ 'lük DTNB çözeltisi ilave edilerek karıştırıldı 5-10 sn sonra oluşan sarı renk oda sıcaklığında iyice stabil hale geldikten sonra 412 nm'de köre karşı okundu (Elman,1959).

\section{Maya Hücresinde Total Protein Miktarının} Ölçülmesi

Örneklerin total protein miktarlarının ölçümü Lowry (1950) yöntemine göre yapıldı

\section{Yă̆ Asidi Miktarının Belirlenmesi}

LPO miktarının ölçümü dışında kalan reaksiyon karışımı üzerine \% $2^{\prime}$ lik metanolik $\mathrm{H}_{2} \mathrm{SO}_{4} \quad$ (v/v) konularak vortekslendi ve 16 saat $55^{\circ} \mathrm{C}$ 'de inkübasyona bırakıld1. İnkübasyon sonunda, soğutulduktan sonra üzerine $5 \mathrm{~mL} \% 5$ 'lik NaCI ilave edildi. Reaksiyon ortamında oluşan yağ asidi metil esterleri $5 \mathrm{~mL}$ n-hekzan ilave edildi (Christie, 1992).

\section{ADEK Vitaminleri ve Kolesterol Miktarının Belirlenmesi}

5 mL süpernatant 25 mL'lik ağzı kapaklı tüpler içine alınarak üzerine \% 5'lik $\mathrm{KOH}$ çözeltisi ilave edildi. Vortekslendikten sonra $85^{\circ} \mathrm{C}$ 'de $15 \mathrm{dk}$ bekletildi. Tüpler çıkartılarak oda sıcaklığına kadar soğutuldu ve üzerine $5 \mathrm{~mL}$ saf su ilave edildi ve karıştırıldı. Sabunlaşmayan lipofilik moleküller $2 \times 5 \mathrm{~mL}$ hekzan ile extrakte edildi. Hekzan fazı azot akımı ile uçuruldu. $1 \mathrm{~mL}(\% 50+\% 50$, $\mathrm{v} / \mathrm{v})$ asetonitril/metanol karışımında çözülerek otosampler viallerine alındı ve analiz edildi. A vitamini için dedeksiyon dalga boyu $326 \mathrm{~nm}$, E vitamini için 202 $\mathrm{nm}, \mathrm{D}$ ve $\mathrm{K}$ vitaminleri için $265 \mathrm{~nm}$ kullanıldı (Katsanidis ve Addis 1999).

\section{BULGULAR ve TARTIŞMA \\ Ăğır Metal Uygulama Gruplarının MDA Miktarı Üzerine Etkileri}

S. cerevisiae hücrelerinde ağır metal uygulamalarının MDA düzeyini artırdığı belirlenmiştir (Şekil 1). Özellikle $\mathrm{Mg}$ ve Cd uygulamalarının MDA içeriğini ciddi seviyede artırdığı ve bu artışların istatistiksel açıdan da önemli olduğu $(\mathrm{p}<0.0001)$ görülmektedir (Şekil 1). Cd uygulamasının MDA içeriğini en çok artıran grup olduğu belirlenmiştir.

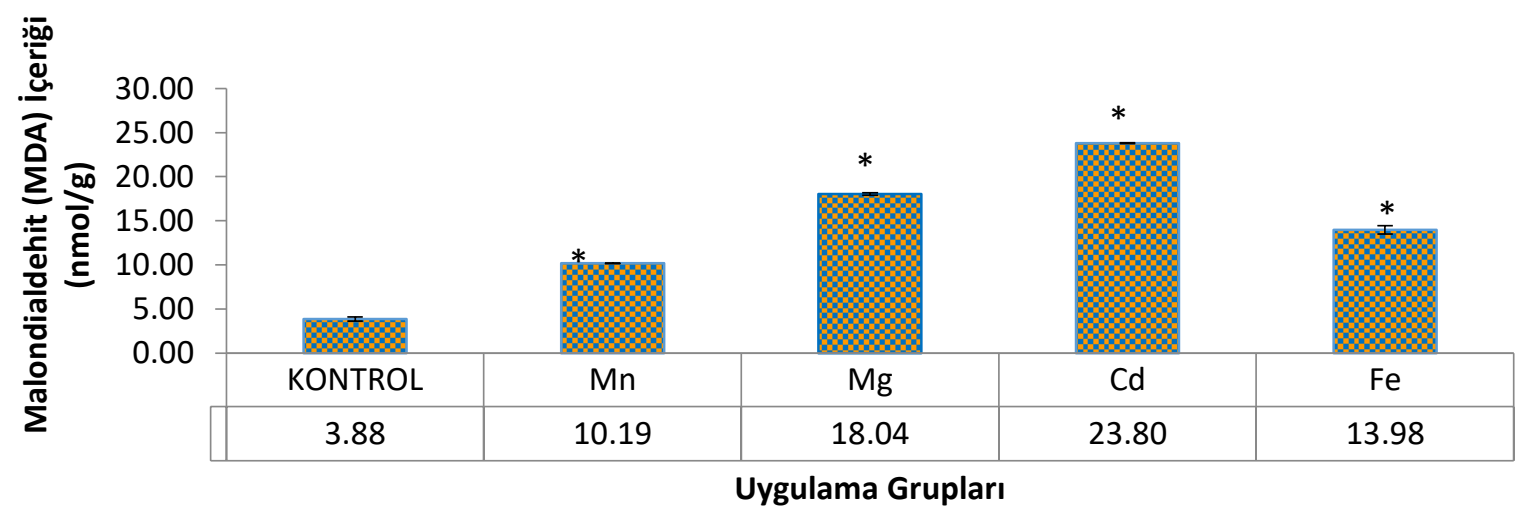

Şekil 1. Uygulama gruplarının S. cerevisiae’ da malondialdehit içeriğine etkileri

Lipid peroksidasyonu; membrandaki doymamış yağ asitlerinin serbest oksijen radikalleri tarafindan alkoller, aldehitler, hidroksi yağ asitleri, etan ve pentan gibi çeşitli ürünlere yıkılması reaksiyonudur. Serbest radikaller özellikleri nedeniyle lipitler, proteinler ve nükleik asitler ile etkileşerek hücreye zarar verirler. Çeşitli patolojik durumlar sırasında birçok hücre tipinde $\mathrm{O}_{2}$ ' nin redüksiyonundan oluşan türlerin üretimiyle oksidatif stres meydana gelir. Bunun sonucunda hücre yapısındaki lipitlerde bozulmalar olur (Rice-Evans ve ark., 1991).
MDA (Malondialdehit), biyolojik sistemde lipitlerin oksidasyonu sonucunda oluşmaktadır. Bu bileşikler ya hücresel olarak metabolize olurlar ya da başlangıçta etkili oldukları bölgeden diffüze olup hasarı hücrenin diğer bölümlerine yayarlar. Lipid radikallerinin hidrofobik yapıda olması dolayısı ile reaksiyonların çoğu membrana bağlı moleküllerde meydana gelir. Membranlarda, reseptörleri ve membrana bağlı enzimleri inaktive etmek suretiyle membran proteinlerinde de ciddi hasarlar meydana getirebilirler ve iyon transportunu 
etkileyebilirler. (Rice-Evans ve ark., 1991). LPO reaksiyonu ya toplayıcı antioksidan reaksiyonlarla sonlandırılır veya otokatalitik yayılma reaksiyonları ile devam eder (Gutteridge, 1995; Dikici, 1999). Bir araştırma ile; ağır metallerden olan kadmiyum uygulaması sonrası lipit peroksidasyonu (LPO)'nun bir göstergesi olan malondialdehitin (MDA) dokularda arttığ1 gözlenmiştir (Asagba ve ark., 2000)

Yaptığımız çalışma sonucunda ağır metal uygulamalarının maya hücresinde MDA miktarını artırdığını belirledi. Ağır metal uygulaması durumunda hücreler ciddi derece hasara uğramaktadır ve lipit oksidasyonunun olmaması kaçınılmazdır. Sonuçlarımıza göre uygulanan ağır metallerin çeşidine ve organizma için esensiyal olması durumuna bağlı olarak artmış MDA miktarları bulunmaktadır. Çalışma sonucunda elde ettiğimiz sonuçlara göre; özellikle $\mathrm{Mg}$ ve uygulamalarında yüksek MDA içerikleri belirlenmiş olup insan beslenmesinde de dikkat edilmesi gerek bir durum olduğu konusu kaçınılmazdır.

\section{Ăğı Metal Uygulama Gruplarının GSH ve GSSG} Miktarları Üzerine Etkileri

A ğır metal uygulamalarının GSH içeriği üzerine etkileri incelendiğinde tüm uygulamaların GSH düzeyini azalttığı Şekil 2'da görülmektedir. Özellikle $\mathrm{Cd}$ ve Fe uygulamalarının GSH üzerine etkilerinin oldukça baskılayıcı olduğu ve elde edilen değerlenin istatistiksel olarak önemli olduğu $(\mathrm{p}<0.0001)$ belirlenmiştir (Şekil 2).

Okside glutatyon (GSSG) içeriği ağır metal uygulamalarına bağlı olarak artış göstermiştir (Şekil 3). Glutatyon içeriğindeki azalmalara paralel artışlar okside glutatyon içeriğinde saptanmıştır. Yapılan istatistiksel analize göre; Cd ve Fe uygulamalarında meydana gelen GSSG içeriğindeki değişmelerin istatistiksel açıdan önemli olduğu $(\mathrm{p}<0.0001)$ saptanmıştır.

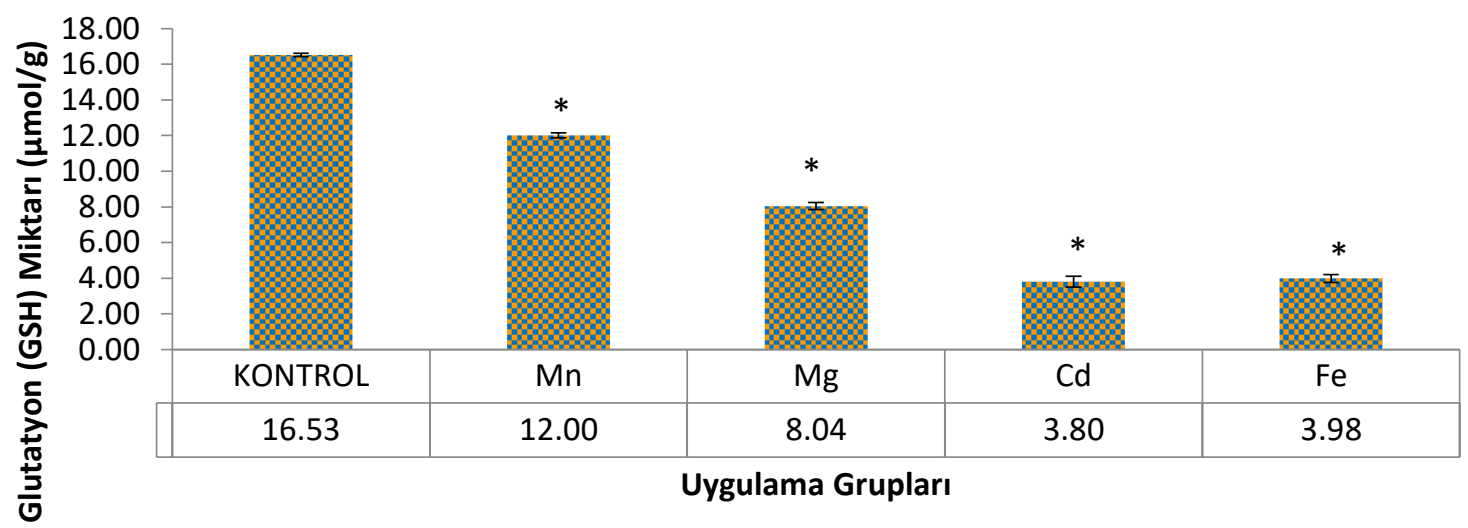

Şekil 2. Uygulama gruplarının S. cerevisiae'da glutatyon miktarına etkileri

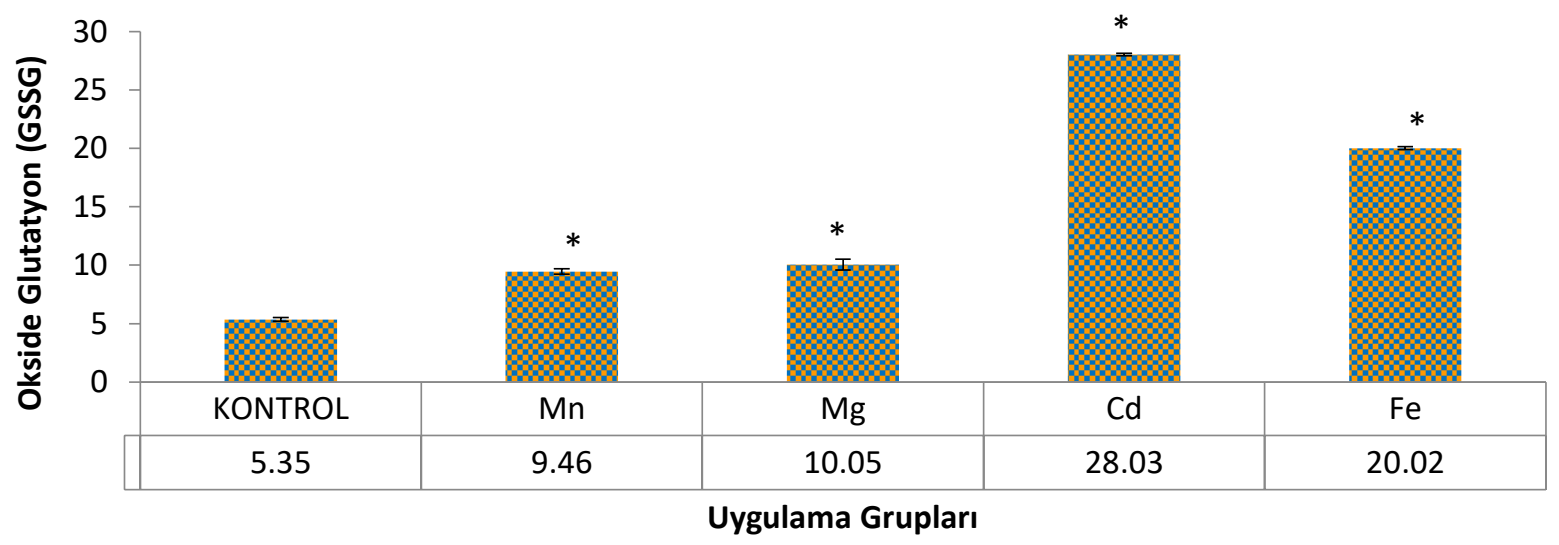

Şekil 3. Uygulama gruplarının S. cerevisiae' da okside glutatyon miktarına etkileri

Oksidatif stresin zayıf olduğu durumlarda devreye giren adaptasyon mekanizmaları sonucunda GSH düzeyi artırılır. Ancak; oksidatif stresin güçlü olduğu durumlarda zayıflayan adaptasyon mekanizmalarına ve 
artan GSSG oluşumuna bağlı olarak GSH düzeyi azalmaktadır (Zhang ve ark., 2005). Hücre içerisinde GSSG'nin GSH'a redüksiyonunu katalizlemekle görevli olan enzim, glutatyon disülfid redüktaz (G; EC 1.6.4.2) olarak bilinmektedir. GSSG miktarının artması durumu ise NADPH üretim yollarındaki herhangi bir bozukluğu göstermekte veya enzimin inaktivasyonu sonucu hücre içi GSH miktarının azalması anlamına gelmektedir. Bu görüşümüz, Izawa ve ark., (1995), tarafindan yapılan çalışma ile de desteklenmektedir. $\mathrm{Bu}$ araştırıcılar tarafindan $\mathrm{H}_{2} \mathrm{O}_{2}$ 'ye karşı oluşturulan adaptasyon mekanizmalarından birinin intraselular glutatyonun artışı olabileceği bildirilmiştir. Ayrıca, Penninckx (2000) tarafından da $S$. cerevisiae mayasının farklı besin kaynaklarına ve oksidatif strese cevap olarak glutatyon sentezlediği belirtilmiştir.

Mevcut çalışma sonucunda; Glutatyon miktarının uygulama gruplarında kontrol grubuna göre azaldığ belirlenmiştir. Okside glutatyon ise artmıştır. Bu sonuç antioksidan enzimler ve MDA içerikleriyle beraber düşünüldüğünde uygulanan ağır metallerin ortamda ciddi derece stres oluşturduğunu desteklemektedir ve literatür ile uyumludur (Garces ve ark., 2001). Meister ve Anderson (1983) tarafindan yapılan çalışmada, oksidanların neden olduğu doku hasarı sonucunda GSSG miktarında artış olabileceğini ve GSH/GSSG oranının değişebileceğini bildirilmiştir. Çalışmamızda literatür ile uyumlu sonuçlar elde edilmiştir. GSG/GSSG oranındaki azalma organizmada ciddi risk oluşturur ki sonuçlarımıza göre GSH/GSSG oranında azalma meydana geldiği belirlenmiş olup bu durum MDA ile toplam çözünebilir protein miktarlarında da gözlenmiştir. Çalışmada özellikle $\mathrm{Cd}$ ve Fe uygulamalarında GSH miktarında ciddi azalma, GSSG miktarında ise artış olduğu Şekil 2 ve Şekil 3'da görülmektedir.

\section{Ăğı Metal Uygulama Gruplarının Toplam} Çözünebilir Protein Miktarı Üzerine Etkileri

Toplam çözünebilir protein miktarı üzerine uygulama gruplarının etkilerinin değişken olduğu saptanmıştır (Şekil 4). Mn ve Mg uygulamalarında kontrol grubuna göre daha yüksek toplam çözünebilir protein miktarı belirlenmiştir. Diğer uygulama gruplarında ise kontrol grubuna nazaran düşük değerler tespit edilmiştir. $\mathrm{Cd}$ ve Fe uygulamalarından elde edilen toplam çözünebilir protein miktarı değerlerinin istatistiksel açıdan önemli olduğu belirlenmiştir $(\mathrm{p}<0.0001)$.

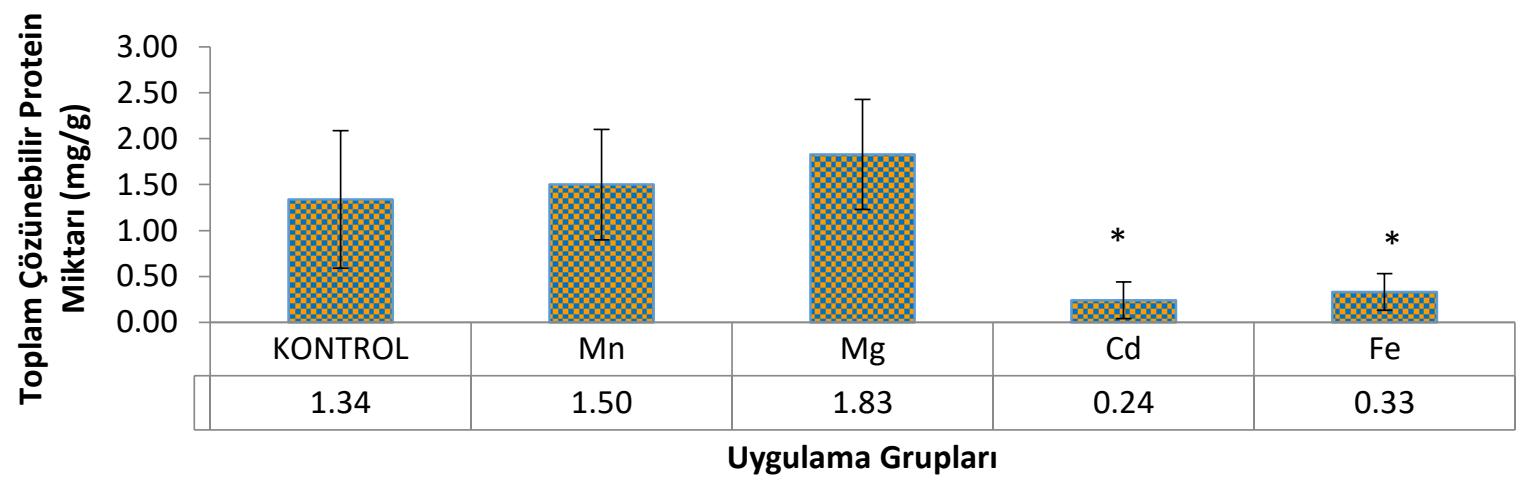

Şekil 4. Uygulama gruplarının S. cerevisiae'da toplam çözünebilir protein içeriğine etkileri

Proteinler sürekli çeşitli içsel ve dişsal faktörler tarafindan zarar görür (Chondrogianni ve ark., 2014). Genel yaklaşıma göre; ağır metaller için ilk hedef organizmadaki proteinlerdir. Ağır metaller özellikle hassas proteinlerin ya işlevsel yan zincir grupları ile bir kompleks oluşturarak ya da Metaloproteinlerde esas metal iyonlarının yer değiştirmesiyle belirli fizyolojik aktivitelere müdahale eder (Tamas ve ark., 2014). Vido ve arkadaşları (2001) S. cerevisiae mayası ile yaptıkları çalışmada, Cd (II) stresine maruz bırakılan maya hücrelerinin stres koşuluna hücresel yanıtını araştırmışlardır. Araştırmada, S. cerevisiae hücreleri ağır metal stresine cevap olarak 54 proteinin sentezini arttırırken, 43 proteinin sentezini azaltttığ sonucuna varılmıştır. Aynı zamanda araştırıcılar tarafından, glutatyon sentezi ile antioksidant özelliğe sahip bazı proteinlerin Cd (II) iyonları ile muamele edilen maya hücreleri tarafından daha fazla sentezlediğini gösterilmiştir. Ting ve Lawson (1991), kromun çeşitli şekillerde membranlara, organellere, proteinlere ve nükleik asitlere zarar verdiğini bildirmiştir. Li ve ark., (2007) tarafından yapılan çalışmada Rhodotorula sp. Y11 mayasının Cd direnci araştırılmış olup, 12 saat sonra içerisinde $\mathrm{Cd}$ bulunmayan ortamda protein miktarının $324.3 \mathrm{mg} / \mathrm{g}$ iken $100 \mathrm{ppm} \mathrm{Cd}$ varlığında $421.7 \mathrm{mg} / \mathrm{g}$ olduğunu, 24 saat sonunda ise her iki ortam içinde azalma gözlendiği ve protein biyosentezinin ise mikroorganizma türüne bağlı olarak değişeceği bildirilmiştir. Yapılan çalışmalara göre; metaller inter ve intrafibriller, parakristalin bölgeler, proteinler, RNA ve polifosfatlar, vakuoller gibi hücre yapılarında alınıma uğramaktadırlar. Genelde hücre duvarlarına metal bağlanması hızlı ve yüksek verimlilik gösterirken hücrenin sitoplazmasındaki bölgelerde çok yavaş ve düşük verimliliktedir. Ayrıca metallerin alınım sürecinde birçok mikroorganizmanın metal bağlayıcı proteinler 
sentezledikleri de rapor edilmiştir (Yazgan ve ark. 1993; Favero ve ark., 1991).

Elde ettiğimiz sonuçlara göre; $\mathrm{Mn}$ ve $\mathrm{Mg}$ uygulamalarında toplam çözünebilir protein miktarında artış olduğu buna karşın $\mathrm{Cd}$ ve $\mathrm{Fe}$ uygulamalarında ise azalma meydana geldiği belirlenmiştir. Elde ettiğimiz sonuçlar Vido ve ark., (2001) tarafindan belirtilen sonuçlarla uyum göstermektedir. Benzer şekilde Li ve ark., (2007) tarafından yapılan ve ağır metal uygulamasının süresine bağlı olarak protein miktarında azalma olduğunu bildirdikleri literatür ile uyumludur. Sonuçlarımız uygulanan metal çeşidine göre protein miktarında değişiklikler olduğunu göstermiştir.

\section{Ă̆ır Metal Uygulamalarının S. cerevisiae'nın Yă Asitleri Üzerine Etkileri}

Miristik asit (14:0) miktarı üzerine ağır metal uygulamalarının etkilerinin tüm gruplarda azaltıcı yönde olduğu belirlenmiştir (Çizelge 1). Kontrol grubunda belirlenen 14:0 miktarının en yüksek düzeyde olduğu, Fe uygulamasında ise oldukça düşük bulunduğu gözlenmiştir $(p<0.0001)$. Ağır metal uygulamalarının palmitik asit (16:0) içeriği üzerine etkileri incelendiğinde kontrol grubu ile karşılaştırıldığında yağ asidinin tüm ağır metal uygulamalarında arttığı ancak bu artışların istatistiksel açıdan önemsiz olduğu $(p>0.05)$ belirlenmiştir. Mn içeren grupta 16:0 miktarının en düşük seviyede olduğu saptanmıştır. Ağır metal uygulamalarının $S$. cerevisiae'nın palmitoleik asit (16:1) içeriği incelendiğinde; kontrol grubuna göre sadece Mn uygulamasında artış olduğu, diğer uygulamalarda azalmaların bulunduğu $\mathrm{Cd}$ ve $\mathrm{Fe}$ uygulamalarında belirlenen 16:1 içeriğinin en düşük seviye meydana geldiği görülmektedir. Heptadekanoik asit (17:0) içeriğine ağır metal uygulamalarının etkileri incelendiğinde tüm ağır metal uygulamalarının 17:0 içeriğini azalttığ 1 , Fe uygulamasında en düşük seviyede 17:0 içeriği bulunduğu ve elde edilen sonuçların önemli $(\mathrm{p}<0.0001)$ olduğu belirlenmiştir. Ağır metal uygulamalarının Stearik asit (18:0) içeriği üzerine etkilerinin yağ içeriğini artırıcı şekilde olduğu ve Fe içeren grupta bu artışın daha fazla olduğu belirlenmiştir. $(\mathrm{p}<0.001)$. Oleik asit $(18: 1)$ ve Linoleik asit $(18: 2)$ üzerine ağır metal uygulamalarının etkileri azaltıcı yönde gerçekleşmiştir. Cd ve Fe uygulamalarında her iki yă asidinin miktarında belirgin oranda azalmanın olduğu saptanmıştır.

Çizelge 1. Ağır metal uygulamalarının $S$. cerevisiae'nın yağ asitleri üzerine etkileri

\begin{tabular}{cccccc}
\hline \multirow{2}{*}{ Yă̆ Asitleri } & \multicolumn{7}{c}{ Uygulama Grupları } \\
\cline { 2 - 6 } & Kontrol & Mn & Mg & Cd & Fe \\
\hline $\mathbf{1 4 : 0}$ & $4.17 \pm 0.2$ & $2.62 \pm 0.01$ & $2.80 \pm 0.003$ & $3.21 \pm 0.02$ & $0.58 \pm 0.06^{\text {cd }}$ \\
\hline $\mathbf{1 6 : 0}$ & $42.9 \pm 0.3$ & $52.01 \pm 0.21^{\mathrm{a}}$ & $53.47 \pm 0.51$ & $54.76 \pm 0.24^{\mathrm{b}}$ & $54.56 \pm 0.21$ \\
\hline $\mathbf{1 6 : 1}$ & $7.93 \pm 0.23$ & $8.62 \pm 0.14$ & $7.38 \pm 0.12$ & $1.36 \pm 0.19^{\text {cd }}$ & $0.50 \pm 0.14^{\text {cd }}$ \\
\hline $\mathbf{1 7 : 0}$ & $2.19 \pm 0.12$ & $1.12 \pm 0.01$ & $1.04 \pm 0.02$ & $0.85 \pm 0.03$ & $0.50 \pm 0.08^{\text {cd }}$ \\
\hline $\mathbf{1 8 : 0}$ & $20.1 \pm 0.12$ & $22.58 \pm 0.33$ & $25.09 \pm 0.11$ & $27.02 \pm 0.8$ & $28.99 \pm 0.08^{\mathrm{d}}$ \\
\hline $\mathbf{1 8 : 1}$ & $5.82 \pm 0.36$ & $3.21 \pm 0.04$ & $3.42 \pm 0.03$ & $2.06 \pm 0.12^{\text {cd }}$ & $2.76 \pm 0.04^{\text {cd }}$ \\
\hline $\mathbf{1 8 : 2}$ & $0.66 \pm 0.02$ & $0.50 \pm 0.19$ & $0.45 \pm 0.31$ & $0.39 \pm 0.03^{\text {cd }}$ & $0.36 \pm 0.1^{\text {cd }}$ \\
\hline
\end{tabular}

cd: $\mathrm{P}<0.0001, \mathbf{d}: \mathrm{P}<0.001$, c: $\mathrm{P}<0.01$, b: $\mathrm{P}<0.05$, a: $\mathrm{P}>0.05$

Mayaların yağ asidi profili üzerine çevre şartlarının nasıl etki ettiği üzerine yapılan çalışmamalarda da benzer sonuçlara ulaşılmıştır. McDonough ve Roth (2004) tarafından yapılan ve mayadan yağ asidi sentezini araştırdıkları bir çalışmada, Schizosaccharomyces pombe'nin iki farklı gelişme ortamında $\left(20^{\circ} \mathrm{C}\right.$ ve $\left.30^{\circ} \mathrm{C}\right)$ palmitik asit, palmitoleik asit (16:1), oleik asit (18:1) ve linoleik asit (18:2) sentezi olduğu bildirilmiştir. Ayrıca çalışma sonucunda $S$. pombe hücrelerinde oleik asit (18:1) sentezinin stearoly CoA desaturaz'in ( $\Delta 9$ desaturaz) kontrolüyle mümkün olduğu da belirtilmiştir. Buna ek olarak son yıllarda yapılan çalışmalarla hem yağ asit sentetaz (FAS) hem de $\Delta 9$ desaturaz enzim aktivitelerinin farklı diyetler yolu ile etkilendiği de ortaya konulmuştur (Ntambi, 1999; Rimoldi ve ark., 2001; Ntambi ve ark., 2002). Martin ve ark., (2006), tarafindan yapılan çalışma sonucunda; $S$. cerevisiae ve diğer mayalarda tekli doymamış yağ asidlerinin $\Delta 9$ desaturase yoluyla doymuş açil CoA öncüllerinden oluştuğu bildirilmiştir. Çalışmada ayrıca $S$. cerevisiae'da desaturaz geni OLE1'in faklı karbon kaynağı, metal iyonları ve oksijen seviyesi içeren farklı uyaranların bir kısmına cevap oluşturduğunu ve gen ekspresyonunun düzenlendiği belirlenmiştir. Çünkü membran yağ asidi bileşimi açı bir şekilde çevresel faktörlerden etkilenmektedir. Ayrıca hücrenin yağ asidi bileşiminin gelişme ortamının karbon kaynağından da etkilenebileceği belirtilmektedir (Benchekroun ve Bonaly, 1992). Torija ve ark., 2002 yilında $S$. cerevisiae'nın yă̆ asidi bileşimi üzerine nitrojen kaynaklarının etkisini araştırdıkları çalışmalarının sonucuna göre, mayanın gelişme ortamı içeriğinin ve çevresel şartların hücre membran yağ asidi bileşimini etkilediği tekrar vurgulanmıştır. Farklı bir araştırmada ise sıcaklık, oksijen ve besin sınırlanması gibi çevresel faktörlerden $S$. cerevisiae mayasının açık bir şekilde etkilenerek plazma membranında bazı adaptasyonlar oluşturduğu saptanılmıştır ve plazma membranlarındaki bu değişikliklerin lipit bileşimindeki modifikasyonlarla açıklanabileceğini ileri sürülmüştür (Beltran, 2008).

Mevcut çalışma sonucunda maya hücrelerinde 14:0, $16: 0,16: 1,17: 0,18: 0, \quad 18: 1$ ve $18: 2$ yă̆ asitleri 
belirlenmiştir (Çizelge 1). Bu asitelerden doymamış olanlar $(16: 1,18: 1,18: 2)$ insan beslenmesinde ve sağlığında çok önemlidir. $16: 1,18: 1$ ve $18: 2$ yağ asitleri üzerine $\mathrm{Cd}$ ve $\mathrm{Fe}$ uygulamalarının azaltıcı etkilerinin çok ciddi olduğu görülmüştür. 14:0 (Miristik asit) hücre membrane oluşumu ve protein bağlanması bakımından önemlidir. Çalışmamızda uygulama gruplarında 14:0 içeriğinin azaldığ 1 belirlenilmiş olup bu sonuç hücre membranının stress şartları ile dejenere olduğu anlamına gelmektedir. 16:0 (palmitik asit) canlı organizmada bulunan ve ilk sentezlenen yağ aside olup daha uzun yağ asitlerinin sentezlenmesini sağlar. Çalışmamızda 16:0 miktarı uygulama gruplarında kontrol grubuna göre çok az miktarda artış gösterdiği belirlenirken 16:1 miktarının $\mathrm{Cd}$ ve $\mathrm{Fe}$ uygulamasiyla ciddi derecede azaldığ anlaşılmıştır. Dokularda lipit peroksidasyonunda meydana gelen artışın çesitli metal iyonlarının aracılık ettiği linoleik asitin katalitik peroksidasyonunun artmasından kaynaklandığı belirtilmektedir (Knight ve Voorhes, 1990). 18:1 (Oleik asit) miktarı da ağır metal uygulamalarında bağlı olarak azalmıştır. Linoleik asit miktarı benzer şekilde ağır metal uygulamalarıyla azalma göstermiştir. Sonuçlar; maya hücresinin ağır metal stresi ile karşılaştığında önemli yağ asitlerinin sentezinin azaldığ 1 ve sentezden sorumlu olan enzimlerin transkriblerinin de inhibe olduğu fikrini akla getirmektedir.

Ăğr Metal Uygulamalarının S. cerevisiae'nın Vitamin ve Fitosterol İçeriği Üzerine Etkileri

S. cerevisiae'da ağır metal uygulamalarının R Tokoferol miktarı üzerine etkileri incelendiğinde tüm metallerin vitamin miktarını azalttığı gözlemlenirken (Çizelge 2) özellikle Mn ve Mg uygulamalarında oldukça düşük miktarlarda olduğu belirlenmiştir $(p<0.0001)$. $\alpha$ Tokoferol vitamin miktarının Cd uygulamasında arttığ $\mathrm{Mn}$ ve $\mathrm{Mg}$ uygulamalarında ise oldukça düşük miktarlarda bulunduğu ve istatistiksel açıdan önemli olduğu $(p<0,0001)$ saptanmıştır. $\mathrm{D}_{2}$ üzerine $\mathrm{Cd}$ uygulamasının vitamin miktarını artırıcı etki yaptığı, diğer uygulamalarının azaltıcı etki gösterdiği saptanmıştır. Mn uygulamasında ise oldukça düşük $\mathrm{D}_{2}$ vitamin miktarı bulunduğu belirlenmiştir $(\mathrm{p}<0.0001) . \mathrm{D}_{3}$ vitamin miktarının uygulama gruplarından sadece Fe uygulamasında kontrol grubu ile arasında istatiksel bir farklılığın bulunmadığı gözlemlenirken, diğer ağır metal uygulama gruplarında ise oldukça düşük seviyede olduğu saptanmıştır $(\mathrm{p}<0.0001)$. Ağır metal uygulama grupları kontrol grubu ile karşılaştırıldığında; $\mathrm{K}_{1}$ Vitamin miktarının bütün gruplarda azaldığı ve bu azalmanın $\mathrm{Mn}$ ve $\mathrm{Mg}$ gruplarında istatistiksel açıdan önemli olduğu anlaşılmaktadır $\quad(\mathrm{p}<0,0001) . \quad$ Ağır $\quad$ metal uygulamalarından $\mathrm{Cd}$ grubunda $\mathrm{K}_{2}$ vitamin miktarını artırdığ1 gözlemlenirken $(\mathrm{p}<0.0001), \mathrm{Mn}$ ve $\mathrm{Mg}$ uygulama gruplarında ise vitamin miktarının kontrol grubuna oranla azaldığı belirlenmiştir.

S. cerevisiae'da ağır metal uygulamalarının fitosteroller (stigmasterol, ergosterol ve betasitosterol) üzerine etkileri karşılaştırıldığında; kontrol grubuna oranla $\mathrm{Mn}$ ve $\mathrm{Mg}$ uygulamalarında oldukça belirgin seviyede azalmalar olduğu tespit edilirken $(\mathrm{p}<0.0001)$, Fe grubunda bütün fitosterollerin miktarlarında artış olduğu saptanmıştır.

Çizelge 2. Ağır metal uygulamalarının $S$ cerevisiae'nın vitamin ve fitosterol içeriği üzerine etkileri

\begin{tabular}{|c|c|c|c|c|c|}
\hline \multirow[b]{2}{*}{$\begin{array}{l}\text { Vitamin ve } \\
\text { Fitosteroller }\end{array}$} & \multicolumn{5}{|c|}{ Uygulama Grupları } \\
\hline & Kontrol & Mn & Mg & Cd & $\mathbf{F e}$ \\
\hline R-Tokoferol & $0.58 \pm 0.1$ & $0.1 \pm 0.01^{\mathrm{cd}}$ & $0.1 \pm 0.05^{\mathrm{cd}}$ & $0.44 \pm 0.03$ & $0.42 \pm 0.08$ \\
\hline$\alpha$-Tokoferol & $6.39 \pm 0.2$ & $0.40 \pm 0.3^{\mathrm{cd}}$ & $0.31 \pm 0.1$ & $7.98 \pm 0.3$ & $6.00 \pm 0.6^{\mathrm{cd}}$ \\
\hline Vitamin $\mathbf{D}_{2}$ & $0.34 \pm 0.3$ & $0.02 \pm 0.01^{\mathrm{cd}}$ & $0.13 \pm 0.03^{\mathrm{d}}$ & $1.13 \pm 0.25$ & $0.18 \pm 0.03$ \\
\hline Vitamin $D_{3}$ & $0.47 \pm 0.05$ & $0.1 \pm 0.02^{\mathrm{cd}}$ & $0.1 \pm 0.03^{\mathrm{cd}}$ & $0.1 \pm 0.04^{\mathrm{cd}}$ & $0.35 \pm 0.04$ \\
\hline Vitamin $K_{1}$ & $1.93 \pm 0.05$ & $0.3 \pm 0.02^{\mathrm{cd}}$ & $0.3 \pm 0.03$ & $1.42 \pm 0.12$ & $1.52 \pm 0.29^{\mathrm{cd}}$ \\
\hline Vitamin $\mathbf{K}_{2}$ & 0.30 .96 & $0.10 \pm 0.01$ & $0.14 \pm 0.09$ & $0.98 \pm 0.39^{\mathrm{cd}}$ & $0.33 \pm 0.01$ \\
\hline Stigmasterol & $21.85 \pm 0.36$ & $0.65 \pm 0.25^{\mathrm{cd}}$ & $0.39 \pm 0.03^{\mathrm{cd}}$ & $22.57 \pm 0.9$ & $26.85 \pm 0.28$ \\
\hline Betasterol & $2.81 \pm 0.02$ & $0.38 \pm 0.03^{\mathrm{cd}}$ & $0.39 \pm 0.03^{\mathrm{cd}}$ & $1.97 \pm 0.2$ & $4.68 \pm 0.04$ \\
\hline Ergosterol & $276.08 \pm 0.3$ & $77.70 \pm 0.8^{\mathrm{cd}}$ & $77.3 \pm 0.12$ & $298.52 \pm 0.98$ & $300.06 \pm 22.23^{\mathrm{cd}}$ \\
\hline
\end{tabular}

cd: $\mathrm{P}<0.0001, \mathbf{d :} \mathrm{P}<0.001$, c: $\mathrm{P}<0.01$, b: $\mathrm{P}<0.05$, a: $\mathrm{P}>0.05$

Steroller ökaryotik hücre membranlarının temel yapısını oluşturur. Mayalardaki temel sterol olan ergosterol membranların akıcılık, geçirgenlik ve membrane bağlı enzimlerin aktivitesi gibi olaylardan sorumludur. Aynı zamanda önemli bir ilaç ara maddesidir ve $\mathrm{D}_{2}$ vitaminin öncüsü olduğu belirlenmiştir (Arnezeder ve Hampel, 1990). $\mathrm{D}_{2}$ vitamini ve kortizon üretiminde kullanılması amaciyla ergosterol maya ekimi ile ticari olarak elde edilir (Shang ve ark., 2006). Yapılan bir çalışmada, yüksek amonyum iyonlarının mayada ergoserol birikimini olumsuz yönde etkilediği rapor edilmiştir (Shang ve ark., 2006). S. cerevisiae oksidatif stres şartlarında raektif oksijen türlerine karşı insan hücrelerindekine benzer bir uyarlamalı yanıt sunar (Cabiscol ve ark., 2000; Zulli ve ark., 1998). Bunun sonucunda ise B6 ve B12 vitamini ile bazı mineraller, fitoseroller ve fenolikler gibi maddeleri üretilir. Membran fosfolipid hidroperoksitlerini alkole indirgeyen fosfolipid hidroperoksit glutatyon peroksidaz (PLGSH-Px) da selenyum atomu içerir ve monomerik 
yapıdadır. Membrana bağlı antioksidan olan vitamin E'nin yetersiz olduğu durumlarda PLGSH-Px tarafindan membranın peroksidasyonuna karşı korunmasını sağlanılır (Halliwell ve Gutteridge, 1990). Yapılan çalışmalar ile farklı karbon, nitrojen kaynaklarının ve $S$. cerevisiae'nın gelişme ortamında bulunan diğer bileşenlerin hücre gelişimini ve ergosterol sentezini etkilediği ortaya konulmuştur (Qian, 1988; Tan ve ark., 2003). Bunun yanında maya hücresinin temel sterolü olan ergosterolün membran yapısının geçirgenlik, akıcılık gibi özelliklerinden ve membrana bağlı enzimlerin aktivitelerinden sorumlu olduğu bildirilmiştir. Mayanın sentezlediği ergosterol, aynı zamanda D vitamini ile kortizon üretiminde ticari olarak sıç̧a kullanılır (Shang ve ark., 2006). Son yıllarda yapılan çoğu araştırma ile mayadan ergosterol sentezinin arttırılması amaçlanmıştır. $\alpha$ tokoferol; E vitamini temsilcisidir ve en yüksek antioksidan aktiviteye sahip olduğu bilinmektedir (Burton ve Ingold, 1986). Örneğin fibroblastlarda $\alpha$ tokoferol takviyesi ultraviyole radyasyona bağlı reaktif oksijen türevlerini ortadan kaldırdığı rapor edilmiştir (Briganti ve ark., 2008). Araştırma sonuçlarımıza göre $E$ vitamin öncüllerinde $R$ tokoferol ve $\alpha$ tokoferol miktarlarında $\mathrm{Mn}$ ve $\mathrm{Mg}$ uygulamalarında ciddi derece azalma saptanırken, $\mathrm{Fe}$ uygulamalarında kısmi azalma belirlenmiştir. Elde ettiğimiz sonuçlar GSH miktarındaki sonuçlarla paraleldir ve GSH'ın antioksidan savunma, elektrofilik ksenobiyotiklerin detoksifikasyonları, sisteinin taşınması ve depolanması, immün tepkinin düzenlenmesi, prostaglandin metabolizmasının düzenlenmesi ve DNA sentezi gibi çok önemli fizyolojik görevleri bulunduğunun bildirildiği literatür ile uyumludur (Lamotte ve ark., 2004). Sonuçlar GSH'ın bu görevlerinin yanı sıra hücre içerisindeki tiyollerin \%50'sini oluşturan GSH; E ve C vitaminleri gibi eksojen kaynaklı antioksidanların kullanılabilirliğini de artırdığını bildiren bilgilerle de desteklenmektedir.

\section{SONUÇ}

S. cerevisiae'ya uygulanan ağır metallerin antioksidan savunma sistemi, yağ asidi ve vitamin içerikleri üzerine etkilerinin araştırıldığı bu çalışma ile esansiyel olsun ya da olmasın ağır metallerin canlı açısından risk teşkil ettiği sonucuna varılmıştır. $S$. cerevisiae bilimsel çalışmalarda tercih edilen ve insan metabolizmasına benzerliği nedeniyle kullanılan ökaryotik bir organizmadır. S. cerevisiae ile yapılan çalışmalar insan vücudunda meydana gelebilecek benzer durumlara karşı model olarak kullanılmaktadır. Çalışma sonucunda hücre ve dolayısıyla organlarda birikim yapan ve uzun vadede toksik etkileri kaçınılmaz olan çeşitli ağır metallerin özellikle yağ asidi ve vitamin içeriği üzerine etkilerinin oldukça değişken olduğu sonucuna varılmıştır. Yapılan literatür incelemesinde araştırılan parametrelerle ilgili bilgilerin kısmen bulunması çalışmanın önemini ortaya koymaktadır ve literature katkı sağlayacağı açıktır.

\section{TEŞEKKÜR}

Çalışma Bitlis Eren Üniversitesi Bilimsel Araştırma Projeleri Koordinatörlüğü'nün (BEBAP 2013.11) desteği ile gerçekleştirilmiştir.

\section{KAYNAKLAR}

Arnezeder C, Hampel WA 1990. Influence of growth rate on the accumulation of ergosterol in yeast-cells. Biotechnology Letters, 12: 277-282

Asagba SO, Isamah GK, Ossai EK, Ekakitie AO 2002. Effect of oral exposure to cadmium on the levels of vitamin A and lipid peroxidation in the eye. Bullet in Enviromental Contamination and Toxicology, 68: 1821.

Avery SV 2001. Metal toxicity in yeasts and the role of oxidative stress. Advances in Applied Microbiology, 49: 111-142.

Beltran G, Novo M, Guillamon JM, Mas A, Rozes N 2008. Effect of fermentation temperature and culture media on the yeast lipid composition and wine volatile compounds. International Journal of Food Microbiology, 121: 169-177.

Benchekroun A, Bonaly R 1992. Physiological properties and plasma membrane composition of Saccharomyces cerevisiae grown in sequential batch culture and in presence of surfactant. Applied Microbiology and Biotechnology, 36: 673-678.

Briganti S, Wlaschek M, Hinrichs C, Bellei B, Flori Eç, Treiber N, Iben S, Picardo M, Scharffetter-Kochanek K 2008. Small molecular antioxidants effectively protect from PUVA-induced oxidative stress responses underlying fibroblast senescence and photoaging. Free Radical Biology and Medicine, 45, 636-644.

Bruins MR, Kapil S, Oehme FW 2000. Microbial resistance to metals in the enviroment. Ecotoxicology and Enviromental Safety, 45: 198-207.

Burton GW, Ingold KU 1986. Vitamin E: application of the principles of physical organic chemistry to the exploration of its structure and function. Accounts of Chemical Research, 19(7): 194-201

Cabiscol E, Piulats E, Echave P, Herrero E, Ros J 2000. Oxidative stress promotes specific protein damage in Saccharomyces cerevisiae. Journal of Biological Chemistry, 275: 27393-27398.

Chondrogianni N, Petropoulos I, Grimm S, Georgila K, Catalgol B, Grune BT, Gonos ES 2014. Protein damage, repair and proteolysis. Molecular Aspects of Medicine, 35: $1-71$.

Christie WW 1990. Gas chromatography and lipids. The oily press, Skodland.

Dikici İ 1999. Akut viral hepatitlerle interferon tedavisi görmüş kronik viral hepatitlerde oksidatif stresin araştırılması. S. Ü. Tıp Fak., Biyokimya Anabilim Dalı, Uzmanlık Tezi.

DoEllman P, Jansen E, Michels M, Van TM 1994. Effects of heavy metals in soil on microbial diversity and activity as shown by the sensitivity-resistance index, an ecologically relevant parameter. Biology and Fertility of Soils, 17: 177-184. 
Ellman GI 1959. Tissue sulfhydryl groups. Archives of Biochemistry and Biophysics, 70-77.

Farres M, Pina B, Tauler R 2016. LC-MS based metabolomics and chemometrics study of the toxic effects of copper on Saccharomyces cerevisiae. Metallomics, 8(8): 790-798.

Favero N, Costa P, Massimino ML 1991. In vitro uptake of cadmium by basidiomycetes (Pleurotus Cl5treatus) Biotechnology Letters, 13(10): 701- 704.

Gaetke LM, Chow CK 2003. Copper toxicity, oxidative stress, and antioxidant nutrients. Toxicology, 189: 147-163.

Guan-Zetic VG, Stehlik-Tomas V, Grba S, Lutilsky L, Kozlek D 2001. Chromium uptake by Saccharomyces cerevisiae and isolation of glucose tolerance factor from yeast biomass. Journal of Biosciences, 26 (2): 217-223.

Gurzau ES, Neagu C, Gurzau AE 2003. Essential metalscase study on iron. Ecotoxicology and Environmental Safety, 56(1): 190-200. DOI: 10.1016/S01476513(03)00062-9.

Gutteridge JM 1995. Lipid peroxidation and antioxidants as biomarkers of tissue damage. Clinical Chemistry, 41: 1819-1828.

Halliwell B, Gutteridge JM, 1990. The antioxidants of human extracellular fluids. Archives of Biochemistry and Biophysics, 280 (1):1-8.

Izawa S, Inoue Y, Kimura A, 1995. Oxidative stres response in yeast: effect of glutathione on adaption to hydrogen peroxide stres in Saccharomyces cerevisia. Federation of Ruropean Biochemical Societies Letters, 368: 73-76.

Katsanidis E, Addis PB 1999. Novel HPLC analysis of tocopherols and cholesterol in tissue. Free Radical Biology and Medicine, 27(11-12): 1137-1140.

Knight JA, Voorhees RP 1990. Peroxidation of linolenic acid-catalysis by transition metal ions, Annual Clinical Laboratory Science, 20: 347-352, İstanbul.

Li ZJ, Yuan HL, Hu XD 2008. Cadmium-resistance in growing Rhodotorula sp Y11. Bioresource Technology, 99. 1339-1344.

Lowry OH, Rosenbrough NJ, Farr AL, Randall RJ 1951. Protein measurement with the Folin-phenol reagent. The journal of Biochemistry, 193: 265- 277.

Mahesh S, Ginzburg Y, Verma A 2008. Iron overload in myelodysplastic syndromes. Leukemia Lymphoma, 49: 427-438.

Martin CE, Oh C, Jiang Y 2006. Regulation of long chain unsaturated fatty acid synthesis in yeast. Biochimica et Biophysica Acta, 1771(3): 271-285.

McDonough VM, Roth TM 2004. Growth temperature affects accumulation of exogenous Fatty acids and fatty acid composit in Schizosaccharomyces pombe. Antonie Van Leewenhock, 86: 349-354.

Meister A, Anderson ME 1983. Glutathione. Annual Review of Biochemistry, 52: 711-760.

Mukherjee A, Das D, Mondal SK, Biswas R, Das TK, Boujedani N, Khuda-Bukhsh AR 2010. Tolerance of arsenate-induced stress in Aspergillus niger, a possible candidate for bioremediation. Ecotoxicology and Environmental Safety, 73(2): 172-182.

Murray RK, Granner DK, Mayes PA, Rodwell VW 1991. Harper's Illustrated Biochemistry, 22. edition, 720.

Nies DH 1999. MiCrobial heavy-metal resistance. Applied Microbiology and Biotechnology, 51: 730750.

Nies DH, Silver S 1995. Ion efflux systems involved in bacterial metal resistances. Journal of Industrial Microbiology, 14: 186-199.

Ntambi JM 1999. Regulations of Stearoyl-CoA desaturase by polyunsaturated fatty acids and cholesterol. The Journal of Lipid Research, 409: 1549-1558.

Ntambi JM, Miyazaki M, Stoehr JP, Lan H, Kendziorski CM, Yandell BS 2002. Loss of stearoyl-CoA desaturase-1 function protects mice against adiposity. Proceedings of the National Academy of Sciences of the United States of America, 99: 11482-11486.

Ohkawa H, Ohishi N, Yagi K 1979. Assay for lipid peroxides in animal tissues by thiobarbituric acid reaction. Analytical Biochemistry, 95, 351.

Ortiz O, Russell M, Daley TL, Baumgartne, RN, Waki M, Lichtman S, Wang J, Pierson RN Jr, Heymsfield SB 1992. Differences in skeletal muscle and bone mineral mass between black and white females and their relevance to estimates of body composition. The American Journal of Clinical Nutrition, 55: 8-13.

Penninckx M 2000. A short review on the role of glutathione in the response of yeasts to nutritional, environmental, and oxidative stresses. Enzyme and Microbial Technology, 26: 737-742.

Qian SG 1988. Ergosterol production in 51 bottle shakenflask experiments. Chinese Journal of Industrial Microorganism, 18(5): 18-23.

Rice-Evans CA, Diplock AT, Symons MCR 1991. Techniques in Free Radicals Research. Vol 22, Elsevier, Amsterdam.

Rimoldi OJ, Finarelli GS, Brenner RR 2001. Effectes of diabetes and insulin on hepatic Delta 6 desaturese gene expression. Biochemistry and Biophysical Research Communication, 283(2): 323-326.

Schützendübel A, Polle A 2002. Plant responses to abiotic stresses: heavy metal-induced oxidative stress and protection by mycorrhization. Journal of Experimental Botany, 53: 1351-1365.

Shang F, Wen S, Wang X, Tan T 2006. Effect of nitrogen limitation on the ergosterol production by fed-batch culture of Saccharomyces cerevisiae. Journal of Biotechnology, 122: 285-292.

Silver S 1996. Bacterial heavy metal resistance: New Surprises Annual Review of Microbiology, 50: 753789.

Sousa SA, Soares EV 2014. Mitokondria are the main source and one of the targets of $\mathrm{Pb}$-induced oxidative stress in the yeast Saccharomyces cerevisiae. Applied Microbiology and Biotechnology, 8(11): 5153-5160.

Tamas MJ, Sharma SK, Ibstedt S, Jacobson T, Christen P 2014. Heavy Metals and Metalloids As a Cause for 
Protein Misfolding and Aggregation. Biomolecules, 4: 252-267; doi:10.3390/biom4010252.

Tan T, Zhang M, Gao H 2003. Ergosterol production by fed-batch fermentation of Saccharomyces cerevisiae. Enzyme and Microbial Technology, 33: 366-370.

Ting YP, Lawson F 1991. The influence of cadmium and zinc on the cell size distribution of the alga Chrorella vulgaris. The Chemical Engineering Journal, 3: 2334.

Todorović S, Giba Z, Simonović A, Božić D, Banjanac T, Grubišić D 2009. "Manganese effects on in vitro development of lesser centaury [Centaurium pulchellum (Sw.) Druce]," Archives of Biological Sciences, 61(2): 279-283.

Torija MJ, Beltron G, Novo M, Poblet M, Guillaman JM, Mas A, Rozes N 2002. Effects of fermentation temperature and Saccharomyces species on the cell fatty acid composition and presence of volatile compounds in wine. International Journal of Food Microbiology, 85: 127-136.

Vido K, Spector D, Lagniel G, Lopez S, Toledano MB 2001. A proteome analysis of the cadmium response in Saccharomyces cerevisiae. The Journal of Biological Chemistry, 276: 8469-8474.

Williams LE, Pitmann JK, Hall JL 2000. Emerging mechanisms for heavy metal transpot in plants. Biochimica et Biophysica Acta, 1465: 104-126.

Yazgan A, Özcengiz G, Alaeddinoğlu G 1993. Studies on metal resistance system in Kluyveromyces marxianus, Biological Trace Element Research, 38: 117-127.

Zhang JF, Liub H, Sun YY, Wang XR, Wu JC, Xue, YQ 2005. Responses of the antioxidant defenses of the Goldfish Carassius auratus, exposed to 2,4dichlorophenol. Environmental Toxicology and Pharmacology, 19: 185-190.

Zouboulis AI, Loukidou MX, Matis KA 2004. Biosorption of toxic metals from aqueous solutions by bacteria strains isolated from metal-polluted soils. Process Biochemistry, 39: 909- 916.

Zulli F, Suter F, Biltz H, Nissen HP 1998. Improving skin function with CM-glucan, a biological response modifier from yeast. International Journal of Cosmetic Science, 20: 79-86. 